Journal of Engineering Sciences, Assiut University, Vol. 38, No. 2, pp. 555-567, March, 2010.

\title{
INDIGENOUS ALKHABRA VILLAGE A SUSTAINABLE COMMUNITY
}

\author{
Mohamed Alnowaiser \\ Associate Professor College of Architecture\& Urban Planning King \\ Saud University
}

(Received November 24, 2009 Accepted January 12, 2010).

\begin{abstract}
Traditional settlement of Alkhabra is an ideal example of a true sustainable built environment. It is comprehensive, protective, ecological, self-sufficient, and integrated with its natural context. The village spatial fabric displays and an organic hierarchy of various spatial systems with great integration and depth of interaction with all human activities.

The spatial-behavioral systems are well intermingled to coordinate between the various human activities with their corresponding domains and their natural environment.

This study uses the spatial-behavioral analysis and sustainability approaches at the different hierarchal levels. These include the context, sustainable spatial systems, perceptions, movement, neighborhoods, plazas, streets and dwellings.

Also some important themes of spatial security, privacy, sociopetality, environmental protection, and sustainability will be covered.
\end{abstract}

\section{INTRODUCTION}

Traditional AlKhabra has been standing out in central Saudi desert for hundreds of years as a great example of a sustained and substantive human settlement.

It is an ideal example of a true sustainable built environment. It is comprehensive, protective, ecological, self-sufficient, and integrated with its natural context. The village spatial fabric displays and organic hierarchy of various spatial systems with great integration and depth of interaction with all human activities.

The spatial-behavioral systems are well intermingled to coordinate between the various human activities with their corresponding domains and their natural environment.

The whole spatial system has been based on a comprehensive sustainability to support and maintain a comfortable standard of living.

The high degree of sustainability in Alkhabra is expressed in its optimal protection and support for its inhabitants which has accumulated along several centuries and different generations. The arrangements of the village and adjacent farms, street systems, continuous compacted blocks, courtyards and plazas, internal building layouts and materials and water wells maintain residents living.

Its planning concept embodies spatial justice for men, women, teenagers, elderly and children.

Thus the village is composed of well integrated behavioral-environmentalspatial systems. It reflects clear multiple systems of sustainability with respect to social contacts, self supporting services and economies. It is planned with external orientation to outside neighboring farms and villages through three main roads. These roads lead 
to the central suq (almajlis), which is the main hub for residents and visitors. While neighborhoods, streets, plazas and dwellings are inwardly oriented.

This study uses the spatial-behavioral analysis and sustainability approaches at the different hierarchal levels. These include the context, sustainable spatial systems, perceptions, movement, neighborhoods, plazas, streets and dwellings.

Also some important themes of spatial security, privacy, sociopetality, environmental protection, and sustainability will be covered.

\section{THE CONTEXT}

Alkhabra is one of the traditional settlements in Al kasseem region in central Saudi Arabia. This area is a desert, but it contains huge deep water reserves, namely Arabic aquifer. Also this area is very fertile and has been called "the bread basket" of the kingdom. Some main valleys run through the region including wadi Arrimah in which this village is located. The village is surrounded by sand dunes and valleys on south and south-east, and farms on the north and west sides. The living standards for the village inhabitants have been sustained for centuries by its own natural and human resources. The integration between farms, natural sources, security wall, village plan, and residents skills, and activities create various interdependent sub-systems of livability.

\section{THEORETICAL BASE}

The theoretical background for this environmental research is based on two fields, which includes sustainability and man-built environment relationships.

"Environmental Sustainability" is very elastic term which has emerged recently, but sustainability has been practiced in one form or another in traditional settlements. Historically it has been apparent in old environments as an unconscious human creation in response to threats, lack of resources, survival instincts and to the harshness of living conditions.

Sustainability is a concept and an application of a very comprehensive, complicated, multi-dimensional and integrated system. These systems include the ability to coordinate between the human, economic, environmental and urban resources in a holistic approach based on ecology, equity, affordability, balance, ration and continuity.

Moreover, sustainable communities respond to the diverse needs of their current and future inhabitants and following generations. Thus an ideal living environment is oriented to support and maintain a substantive quality of life for residents.

There are various definitions for sustainability each is tailored to certain condition, since no one definition can capture the whole picture. The World Commission on Environment and Development (WCED) cited in G. Haughton defined it as follows:

Sustainable development is development which meets the needs of present without compromising the ability of future generations to meet their own needs. 
Haughton G. et.al (1996) argued that a sustainable development must be based on three principles: inter-generational equity, ultra-generational equity and trans frontier responsibility.

While Mayur (1990) explained that a sustainable city or settlement is being green and by definition living. Here the full potentials of all the intricately interconnected forces of nature are realized. The livability of such environments and its resources create their survival capacity.

Center for Sustainability Community (CSC) defined sustainable community as creative and posses the artful way of living, where people and nature intermingle through thoughtful planning. This is reflected in the articulation, utilization and maintenance of natural and human resources.

The relationships between human and built context varied throughout primeval, farming, urban, industrial and global interdependence phases of development.

Sustainability existed in some traditional environments in a simple form concerning basic needs of survival. However, in recent decades human settlements have grown to be very large and complicated which required a more conscious efforts to sustain them. Thus, sustainability became a necessity to counter the emerging urban problems.

The other aspect of the traditional environment theoretical base is concerned with man-built environment associations. Some authors gave various labels to the traditional environments which all have been categorized in one called, substantive environment. These researchers analyzed the traditional environment being symbolic, emotional, authentic, and sacred. Also it is sociopetal, unselfconscious, unified, organic, spiritual, original, communal and unique (AlNowaiser1985, Altman 1976, Rapoport 1972, Relph 1976, Tuan1977. Porteous 1977).

Alexander (1965) explained the traditional socio- fabric as a semi-lattice. This means the relations between human behavior and the spatial context is more complex and interwoven.

Also Relph (1976) describes the experience of the traditional built environments as one of a deep association of existence; a cultural and communal awareness; and with psychological and biological extensions.

Inhabitants usually conceptualise spaces as symbolic or perceptual .A physical symbol is a part that may represent the whole. For instance a crescent would symbolise Islam, a cross symbolises Christianity, and a circle symbolises perfection and wholeness (Relph 1976, Tuan 1974,1977, Penn 2003)

\section{SUSTAINABLE SPATIAL SYSTEM}

Alkhabra plan reflects a clear sustainability between the inhabitants living needs, the harsh desert environmental forces, the meager resources and the lack of any external support. There are different levels of associations between the above components. These are at the context, village and neighborhood levels. The whole village life is maintained by surrounding farms as food sources and some jobs opportunities. Also farms are irrigated by rain where the main valley provides a water source for most of the farms, through deep wells. 
Within the village there are different subsystems that co-exists and sustain each other. These include social, environmental and built environment subsystems. The social subsystem is explicit in the form of an hierarchy of relationships containing the individuals inside the single family within a multi family and linked with other families to form a neighborhood.

The spatial sub-system of Alkhabra is based on a hierarchal spatial organization. This involves territorial systems of streets and courtyards and plazas. Also this expresses a clear balance and transition from the very private to the very public, within a territorial order. Moreover it presents other spatial dialectical expressions for male, female, boys, girls, Children and elderly in their corresponding places and right of ways (Fig 1).

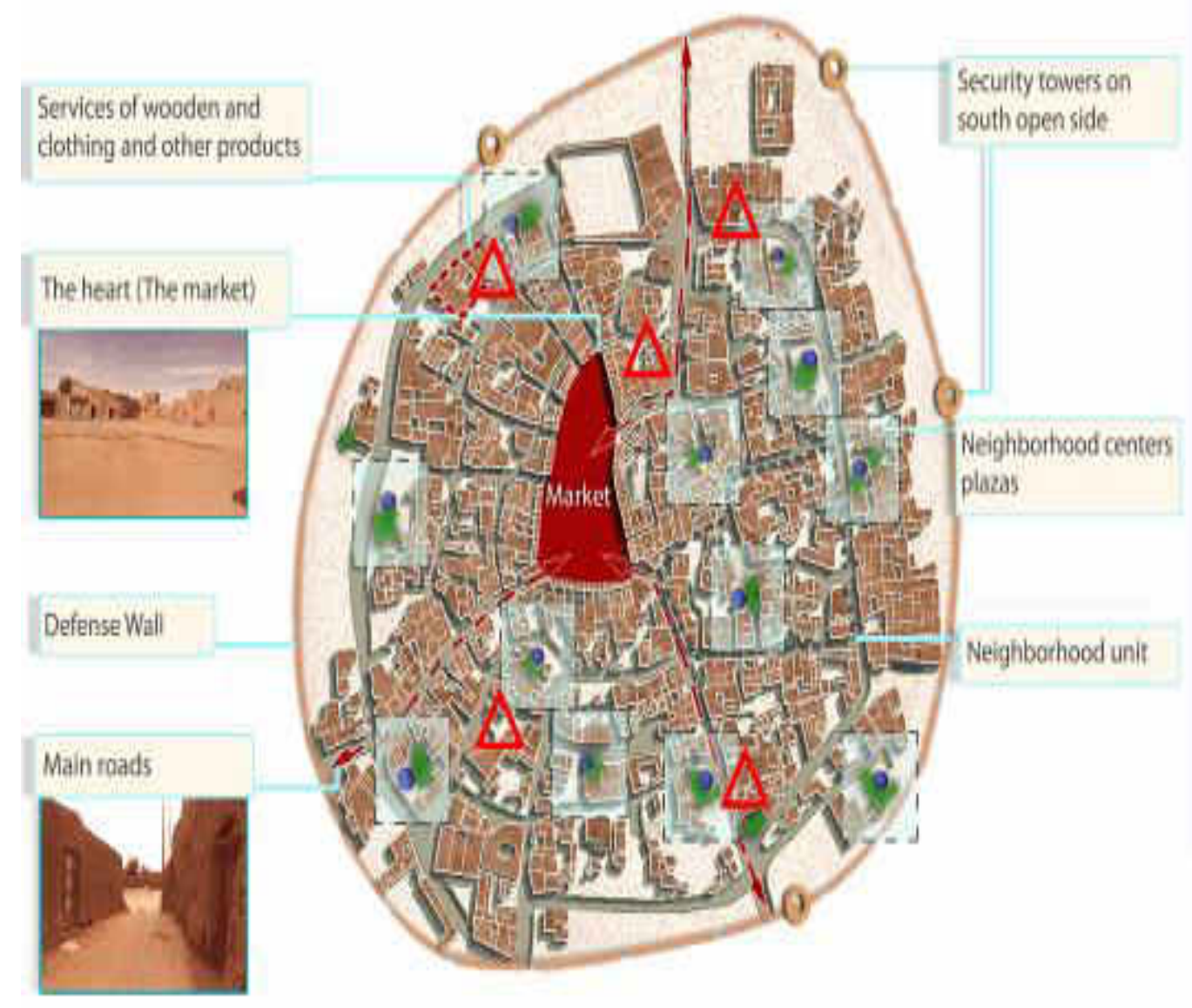

\section{(Fig 1) Al Kabra Components}

There are three residential time - spatial spheres or stages. These represent three historic development of the village. The first established one is the central area with first settlers and smallest houses. The second area is in the middle with first 
migrants and with medium size houses. The third outer area was inhabited by more recent arrivals including some Bedeuins and with largest homes. These areas are not spatially or socially very clear (Fig. 2).

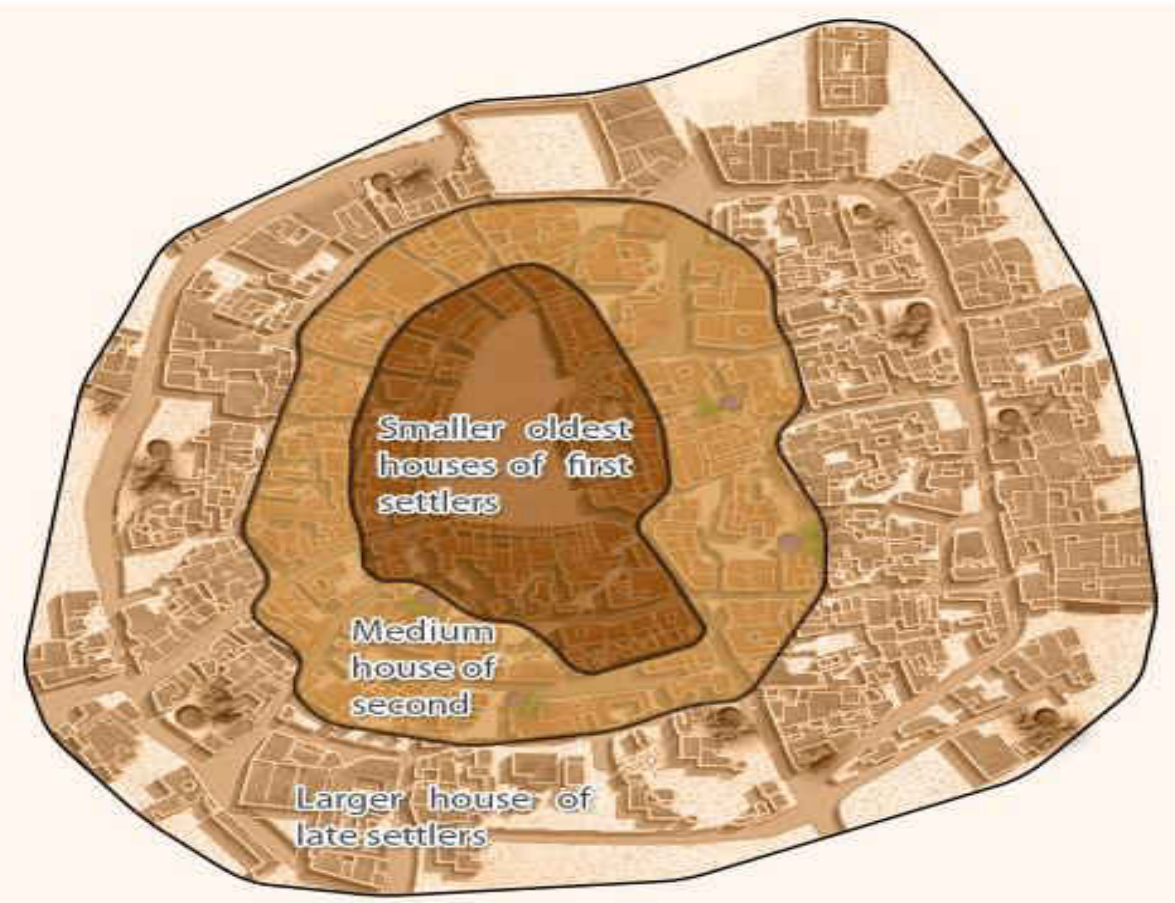

(Fig 2) Historical stages of settlement

The whole village is composed of several neighborhoods of mixed social enclaves and often separated by public streets. Their neighborhoods are inwardly oriented to their main plazas and the houses towards courtyards.

The public realm of Alkhabra sustainability is interwoven in its ability to provide bonds with its dwellers with respect to their symbolic and functional needs. These are apparent by its powerful unique features which impact the inhabitants perceptions, security, movement systems, privacy, territoriality, sociopetality and environmental protection.

\section{PERCEPTIONS}

The main market place and plaza (Suq), the main Friday mosque and its tall minaret and adjacent sand dunes and farms form the main resident's image of the village. Inhabitants associate their perceptions and activities with different spatial symbols and corresponding socio-cultural norms. These include every unique street, courtyard, Plaza, community center, defense wall, water well, tree, minaret, social places, surrounding farms and sand dunes. 
Also perceptions of environmental symbols such as the sky, moon, stars and palm trees decorate artistic expressions on entrances, guestrooms, furniture and coffee and tea pots (fig 3 ).
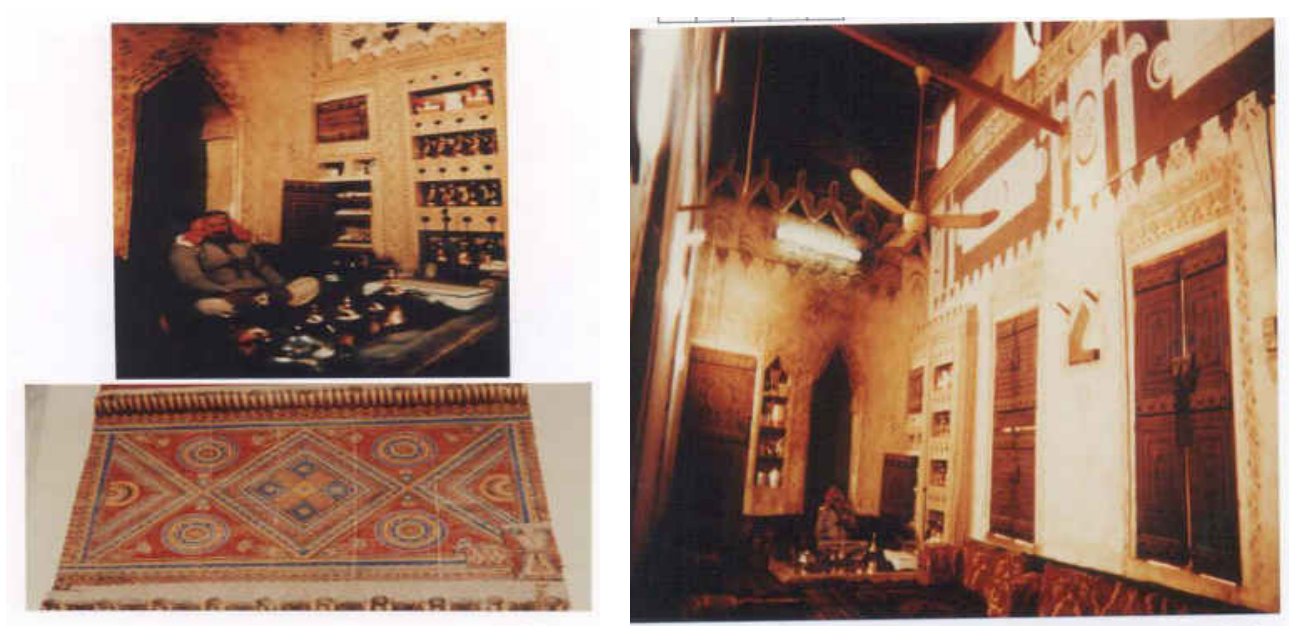

Fig. 3 Environmental perceptions of moon, stars, and palm trees

\section{SUSTAINABLE SECURITY}

The village has been established more than 300 years ago. During that time, the state of Saudi Arabia has not come into existence yet. There was no oil, no electricity, and no security. Resources were very scares and villages were under constant threat of bandits. Therefore, the village used a multiple systems to defend itself, including a perimeter wall, watch towers, long outer blocks and limiting access. The wall surrounds the whole village from all sides with several watch towers. Most of the towers are located toward the barren open desert. While fewer towers are positioned on more secure other sides, where sand dunes and farms are located on the south, north and west sides and create a security zone.

Also the village has three controlled gates. This is supported by surrounding continuous blocks to limit outside access to village neighborhoods (Fig. 4).

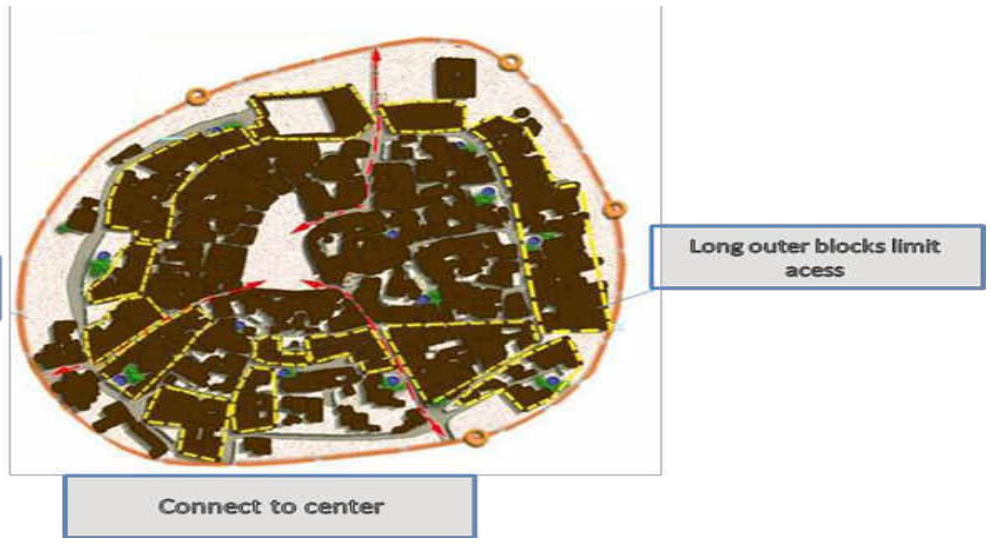

Fig. 4 The security approaches for the village 
Neighborhoods and dwellings are inward oriented and focused around their plazas and courtyards and controlled accesses with fewer openings.

Moreover, each dwelling is well protected access to the inside is controlled by building mass on property lines with very small outside openings. The main large windows are oriented toward the central courtyard of the home. Therefore, such spatial arrangements sustain resident's security.

\section{MOVEMENT}

The movement and activities are organized in a hierarchal order. The first is in the form of three main roads lead in and out of the village for trade exchanges with farmers and visitors, especially those coming in camel carriages. The second is a secondary circular road which distributes some of the incoming movement to the different neighborhoods. The third is a network of distributer streets that connect neighborhoods. Then fourth and the last level is the many access passages going inside small groups of houses. The whole movement system scale has been planned for service animals (camels and donkeys) and pedestrians (fig 5).

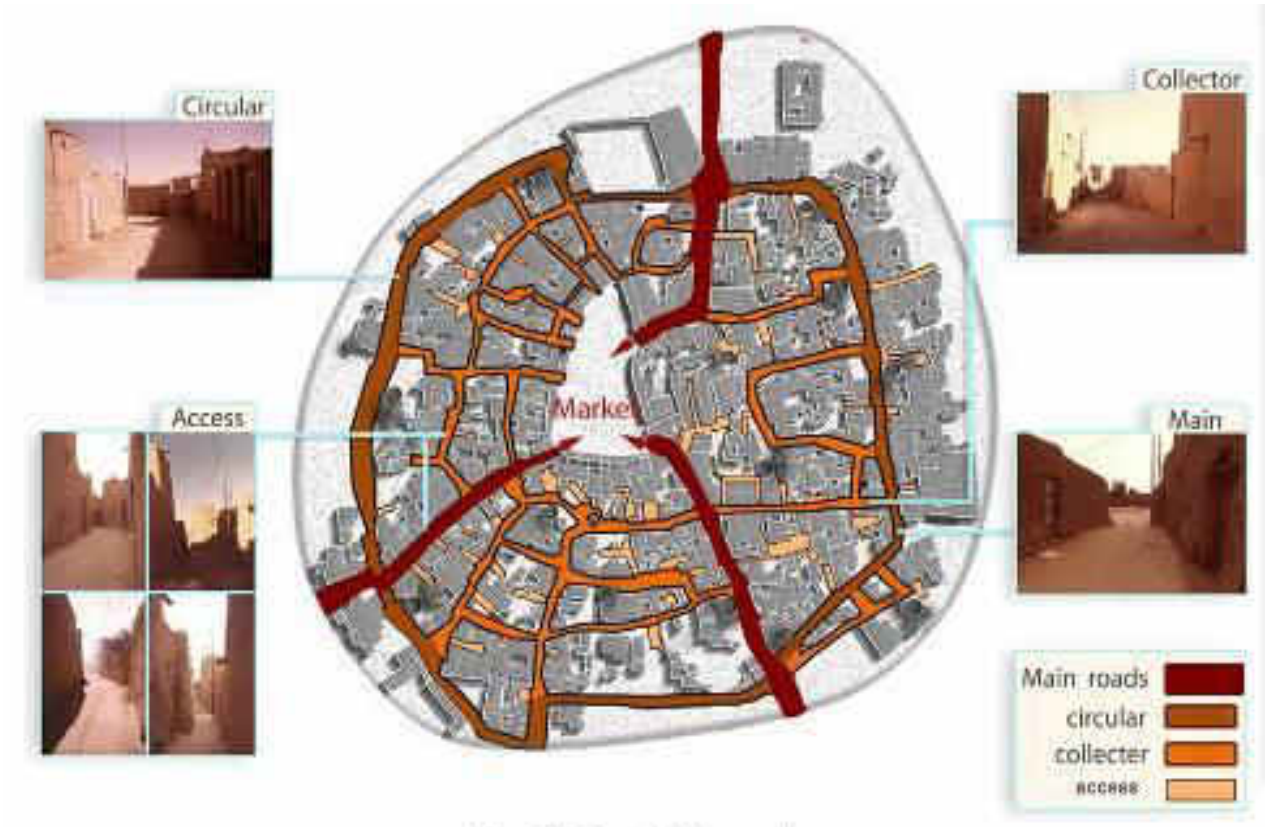

(Fig 5) Road hierarchy

\section{PRIVACY, TERRITORIALITY, AND SOCIOPETALITY}

A hierarchy of private and public spatial system is very clear in Alkhabra structure plan. This is apparent in the territorial transition from the very private home to the very public market place. 
There is a chain of territorial spatial-behavioral sequence starting from the private dwelling to the semi-private cul-de-sac and plaza, collector street, neighborhood center, main and curricular roads to the main suq.

The dwelling design and its adjacent environment balance the female privacy and the male public domains. The house is usually positioned between a private cul-desac or small courtyard and a public street. Usually the private side is exclusively used by women and children wearing relaxed home dresses. This side has the women entrance which opens in semi private shared spaces with neighbors. Also here little children play under the supervision of their mothers. On the other side would be the men's entrance, which opens onto the more public street. Thus the men's public side leads to the more open side of the house. Here would be the main decorated large front door which is usually open and leads to the large pleasant guestroom through a small courtyard. This side is characterized by openness as an expression of hospitality and sociopetalilty towards neighbors and visitors. These two forces of private and public adjacent spaces clearly influence the balance of the house design. (Fig 6-A,B)
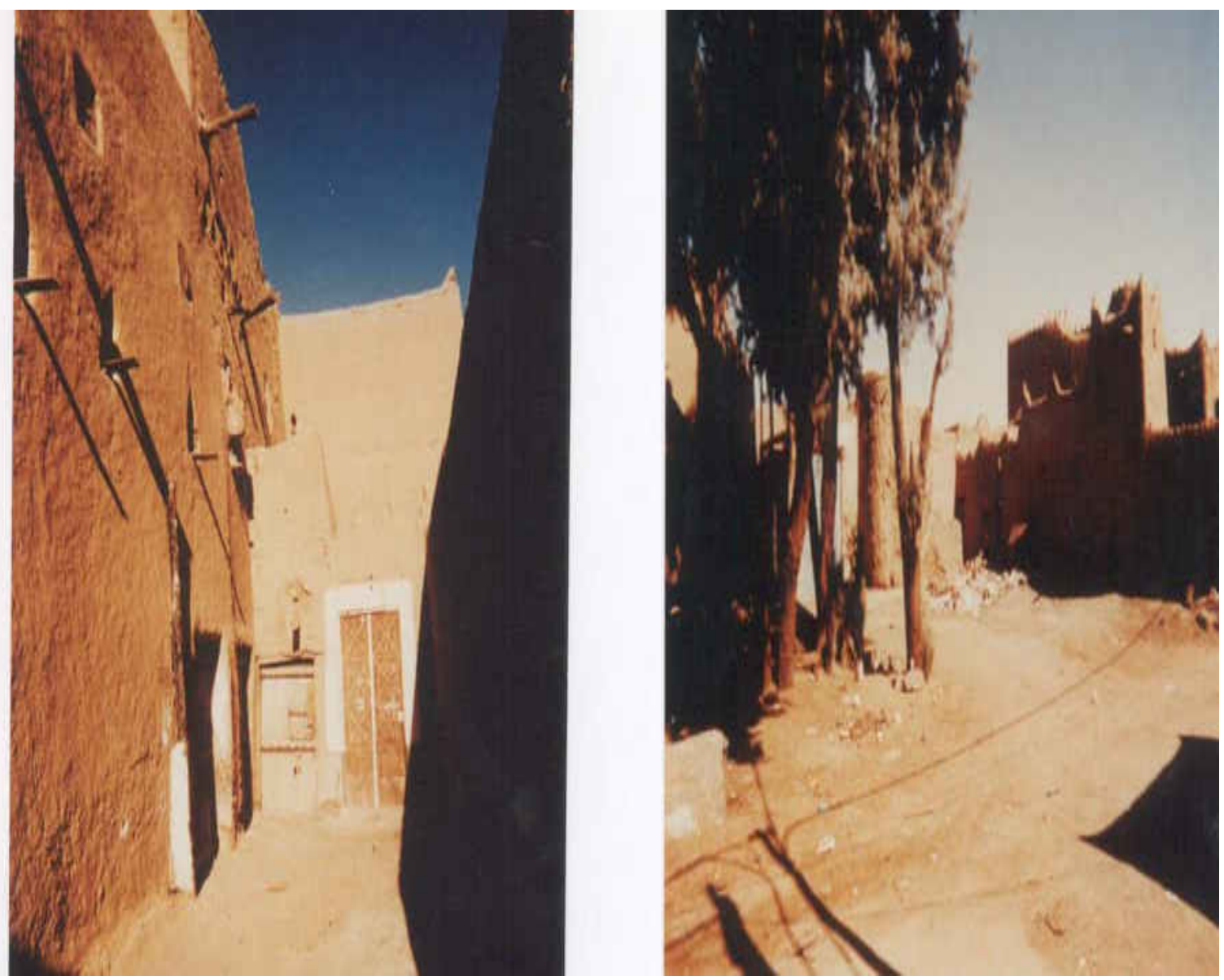

(Fig. 6-A) The balance between privacy and sociopetality 


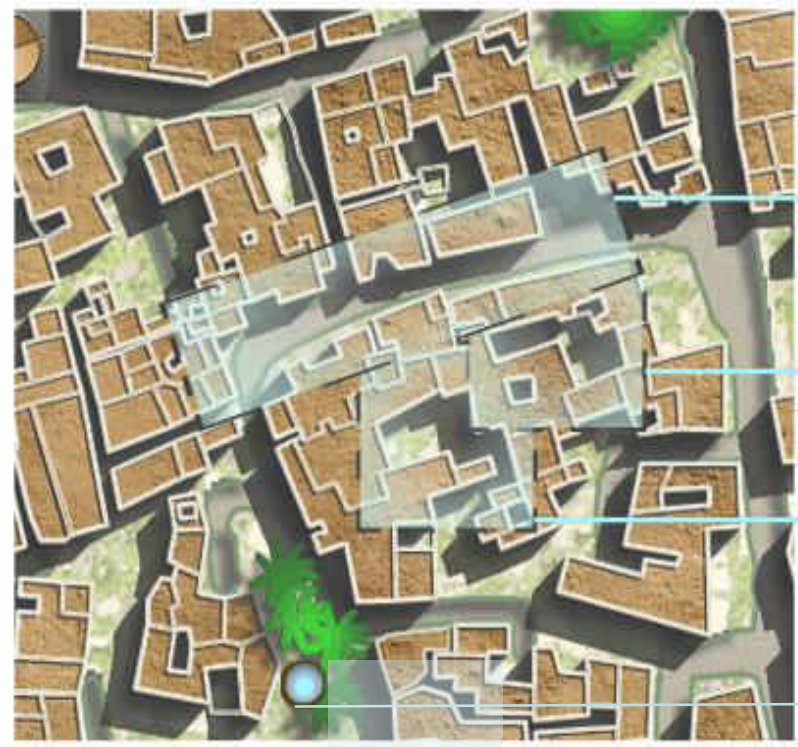

The men's public side at the

home on a through street

Nieghbors women's private plaza and house entrances

(Fig. 6-B) The balance between private and public domains

Also in outer public areas between neighborhoods, spatial domains are provided for women, children, boys and men.

The unique women's social domain include a water well, little mosque, mud and stone seats and a female store for children and women. These elements expand the women spatial opportunities outside of their house (fig 7).

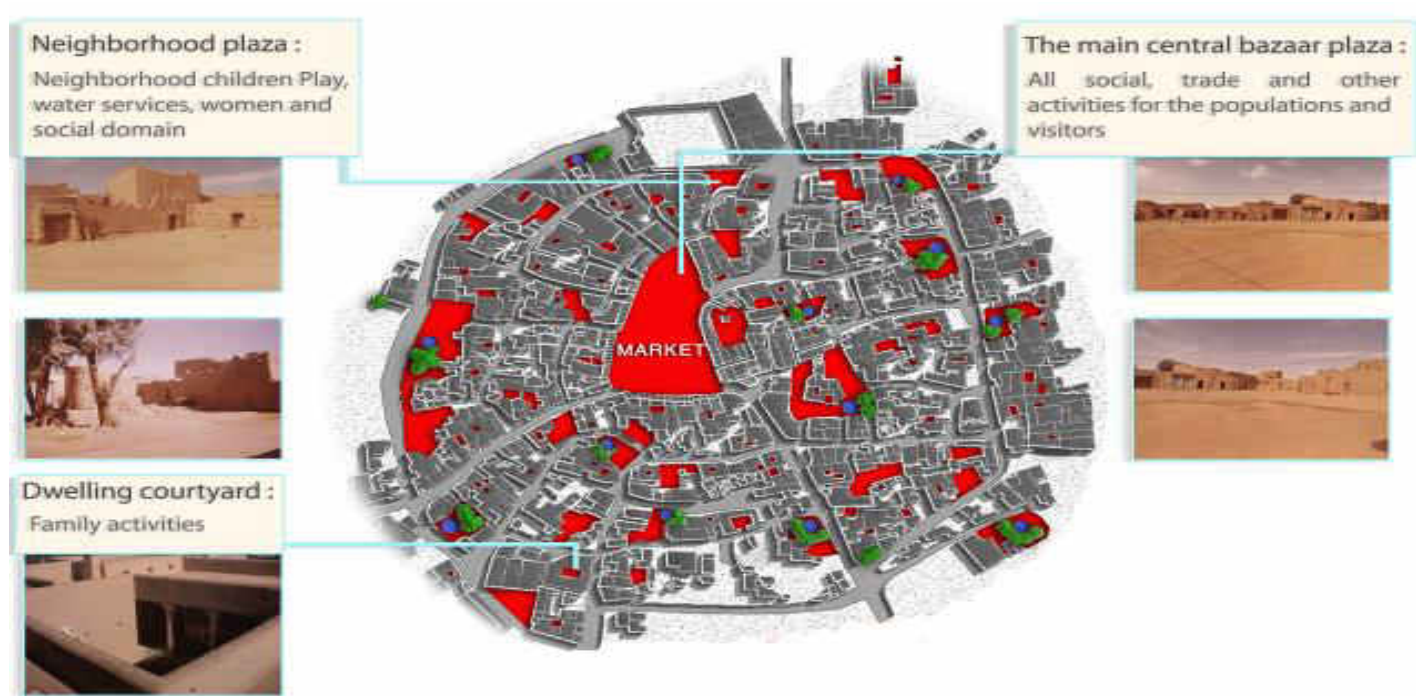

(Fig. 7) Plaza's hierarchy

Since the whole village is compact, most destinations are within a walking distance of 400 meters. Men gather in the large open market place plaza around stores 
and other activities. There they sit, socialize, trade, contact outside visitors, and watch other activities.

Also there are certain covered places for young boys called "Al Kubahs". There boys meet to interact and play different traditional games.

Thus the village provides an equitable spatial environment and facilitate the healthy social contacts between men, women, girls, children, and boys (fig 8).

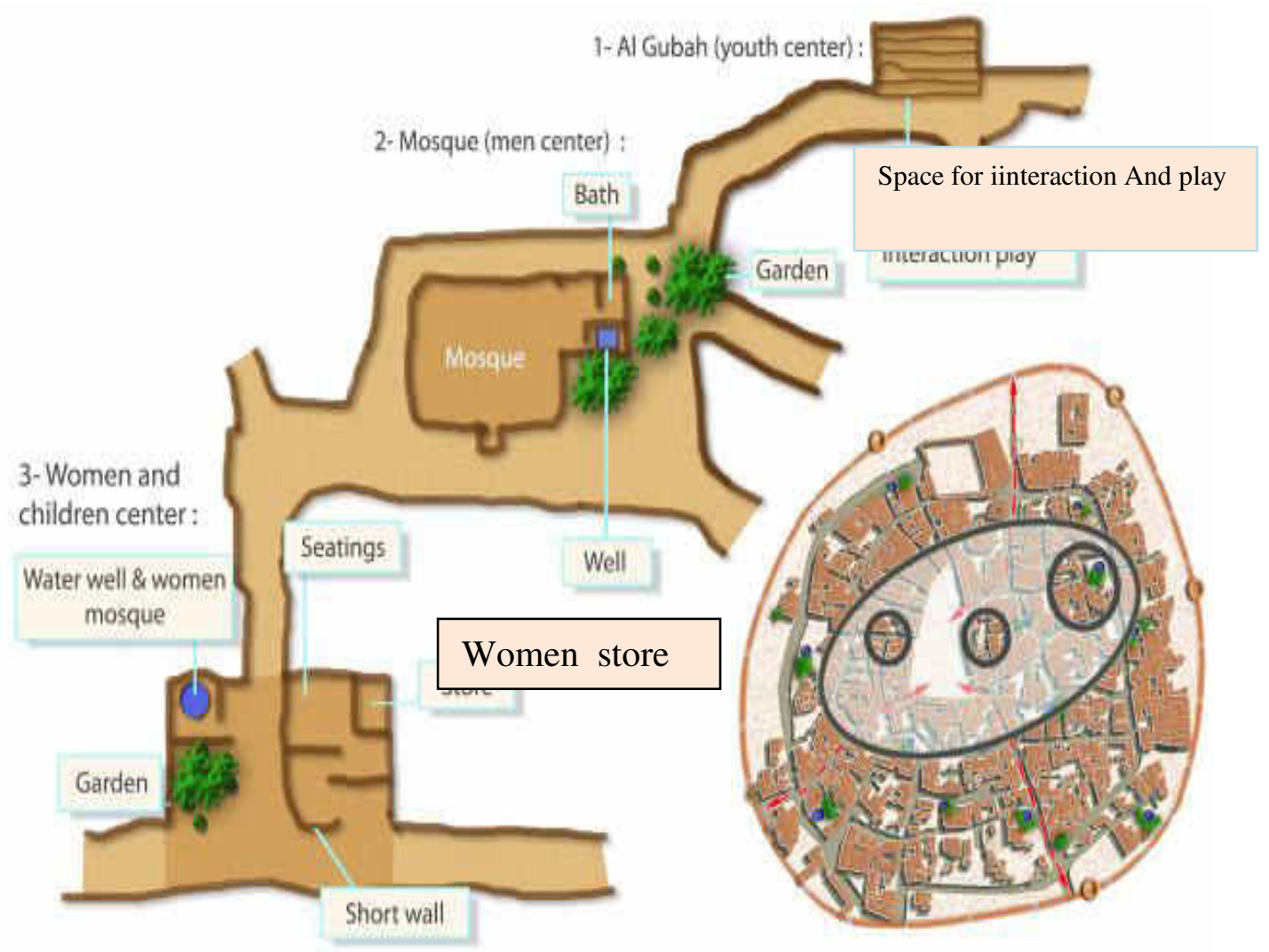

(Fig. 8) A Sample of social domains

\section{ENVIRONMENTAL PERFORMANCE}

The village orientation and design of streets, blocks, and buildings emphasize environmental protection.

The long south and southeast blocks block the sand coming from sand dunes in those directions. Thus, we can notice accumulated blocked sand on these sides of the village, while no sands accumulates on other sides.

The continuous long blocks, the compact and connected building bulks, and the use of mud as the main building material decrease the internal temperature of neighborhoods and dwellings. Houses shade the narrow streets, building and open spaces surfaces for a long time. 
Cool air movement is enhanced by the narrow streets and the placement of small windows in the upper part of the walls, while large windows are placed low in the walls facing the inside of the house.

All these measures make the village environment cooler in the summer and warmer in the winter (Fig. 9).

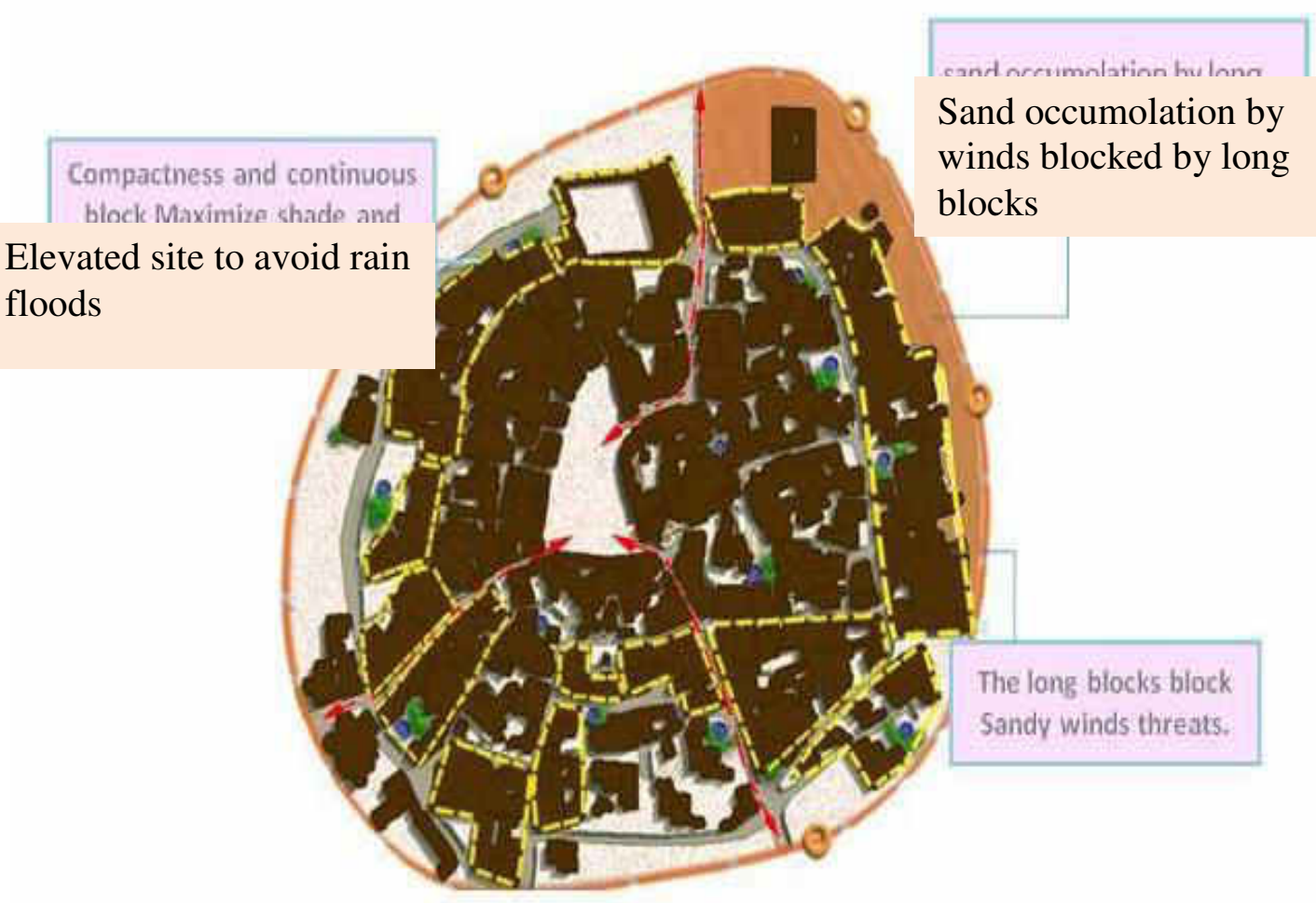

Fig. 9 The compactness of buildings, narrow shaded streets and mud building materials provide a micro-climate with lower temperature and channeled winds

\section{CONCLUSION}

All the above has formed Alkhabra spatial concept to embody very comprehensive and well integrated sustainable systems. These are expressed at the macro and micro levels. The village is externally sustained by its context of farms, sand dunes, and Arrimah valley. These provide complete water, food, energy, clothing, cookware and building material and other support services. Also there are various social, economic environmental dimensions which mutually interact to create a livable context in this harsh desert milieu.

The defensive wall and the inward orientation of the village and the control of neighborhood and dwelling accesses provide security. So the village provides complete, equitable and balanced spatial domains for all age and sex categories.

The hierarchal, territorial and specialized spatial systems arrange for privacy and sociopetality. Thus there is a hierarchy of spatial settings parallel with territoriality of privacy and sociopetality needs for neighbors, women, children, boys, elderly 
women and men. The community centers, plazas, streets, Al Kubas (covered streets) cull- de-sacs and others are distributed at different levels of the village to sustain inhabitants various activities. For example there are specialized plazas for women and for boys activities while the main central plaza is used mostly by men.

Other dimension of sustainability is in the services sector in which the village is self sufficient. The water wells, tailors, carpenters, shoe and cookware makers, food store and natural medicines are distributed through out the village.

Also at the house level and among neighbors food processing, dressing, house building, health care, toys, and energy materials are home made. The family members make all kinds of toys from recycled materials including wood, sheep bones, cans, trees, nails, stones, sand and others. Even desert water coolers (algerbah) are made at home from sheepskin.

The neighborhood center functions are also sustained. The water us used by women for ablution and flows from water carriages to irrigate the garden, where it irrigates tall tamarisk trees that create shade for children play.

Also the village streets, plazas, and buildings orientations, design and materials sustain resident activities by moderating its harsh environment (Figs. 1-8).

Alkhabra traditional settlement is a well of urban planning lessons which are useful for the present. It emphasizes some substantive socio-economic-planning principles. These included the most important spatial concepts of security, sociopetality, sustainability and environmental Protection.

Thus sustainability has been unselfconsciously embedded in the process of choosing the site and planning concept of Alkhabra.

\section{REFERENCES}

1 Alexander Christopher," The city is not a tree", Architecture Forum 58-62, April 1965; 58-61, May 1965.

2 Al Nowaiser M. (1985): Traditional and modern settlements in Saudi Arabia, Habitat International, Vol. 9:1.

3 Al Nowaiser M. "A Conceptual Base of the Role of the Built Environments of Environmental Experience in Central Saudi Arabia" Journal of Architectural and Planning Research 1987.

4 Altman, I. (1975), The Environment and Social Behavior: Privacy, Personal Space, Territory, Crowding, Monterey, Ca. Brooks/Cole Pub., Co.

5 Moos R (1976) Conceptualization of human environments. In H Proshansky, W Ittelson, and L Rivlin (Eds.), Environmental Psychology: People and Their Physical Settings. New York: Holt, Rinehart and Winstron.

6 Penn, A. , Space Syntax and Spatial Cognition, Environment and Behavior 1, 2003, vol.35.

7 Porteous,J. Environment and Behavior: Planning and Everyday Urban Life. Addison-Wesley Publishing Co.,Reading MASSACHUSETTS, 1977.

8 Rapport A (1980) Cross-cultural aspects of environmental design. In I Altman, A Rapport, and J Whohwill (Eds.), Environment and Culture. New York: Plenum Press.

9 Relph, E. Place and placeness, PION, London, 1976. 
10 Stea D, Downs R (1973): Image and Environment: Cognitive Mapping and Spatial Behavior. Chicago: Aldine Publishing Company.

11 Tuan,Y. Topophilia. Prentice-Hall, Englewood Cliffs, New Jersey ,1974.

12 Tuan ,Y., Space and Place. University of Minnesota Press ,Minneapolis ,1977.

13 World Commission on Environment and Development (WCED), Our common future, Oxford University Press, 1987.

14 Haughton, G., Sustainable Cities, J. Kingsley Publishers, London, 1996

15 Mayur, R, Vision and joy of green cities. In D. Gordon, 1990

16 Dr. Hatem G. etc., Urban Development Associated with Sustainable Community - Case study of Siwa Oasis, Cairo Egypt. 2008.

17 Mathew P., Developing lifecycle models for Sustainable Investment in Desert Communities, Murdoch University, Perth. 2008

\section{" قـرية الخبراء التقليدية المستدامة "}

تمثل قريـة الخبراء التقليديـة نمطاً فريداً من ناحيـة تخطيطها الذي يركز على مرين جوهريتين هما الاستدامة والتلازم بين النسيج العمراني والبعد الإنساني. حيث يتضتح ذلك بشمولية مخططها من ناحية تركيزه على أساسيات المستوى المعيشي للسكان والمتمنلة بنظامها الايكولوجي والعضوي , وهذا يندمج مع أبعاد أخرى مدعمة لذلك كالحماية الأمنية والبيئية وتوفير الخصوصية والمرافق الاجتماعية . حيث يلاحظ إن هناك سلاسل من الأماكن والفراغات التي تحتوي على أنواع أنشطة السكان وبمحتوى استدامة متعدد الأبعاد ـ لذا محيط ومحتوى القربة عمل على استدامة واستمرارية وحماية حياة الأهالي على مـر القرون. وتبـرز نواحي الاستدامة بكون القربـة ذاتيـة التشـغيل من ناحيـة البناء والصناعات الحرفية والملابس والمواد الغذائية والتزفيه وحتى العاب الأطفال ـ أيضـا هنالك تداخل وتمازج مع البيئة الصحراوية من ناحية الزراعة والتشجير وتربية الحيوانات والدواجن واستخراج وتدوير المياه وغيرها. لذا تركز هذه الدراسة على تحليل وإبراز جوانب الاستدامة والتلازم بين مخطط وعناصر القرية وحياة وأنشطة السكان وارتبـاط ذلك بالمحافظـة على المصـادر المحليـة والاستمرارية في التتميـة مـع اعتبـار الأجيال المتعاقبة . 